\title{
Aquatic herbivores facilitate the emission of methane from wetlands
}

\author{
Bas J. J. Dingemans, ${ }^{1,3}$ Elisabeth S. Bakker, ${ }^{2}$ and Paul L. E. Bodelier ${ }^{1,4}$ \\ ${ }^{1}$ Department of Microbial Ecology, Netherlands Institute of Ecology (NIOO-KNAW), Droevendaalsesteeg 10, \\ $6708 \mathrm{~PB}$, Wageningen, The Netherlands \\ ${ }^{2}$ Department of Aquatic Ecology, Netherlands Institute of Ecology (NIOO-KNAW), Droevendaalsesteeg 10, \\ 6708PB, Wageningen, The Netherlands
}

\begin{abstract}
Wetlands are significant sources of atmospheric methane. Methane produced by microbes enters roots and escapes to the atmosphere through the shoots of emergent wetland plants. Herbivorous birds graze on helophytes, but their effect on methane emission remains unknown. We hypothesized that grazing on shoots of wetland plants can modulate methane emission from wetlands. Diffusive methane emission was monitored inside and outside bird exclosures, using static flux chambers placed over whole vegetation and over single shoots. Both methods showed significantly higher methane release from grazed vegetation. Surface-based diffusive methane emission from grazed plots was up to five times higher compared to exclosures. The absence of an effect on methane-cycling microbial processes indicated that this modulating effect acts on the gas transport by the plants. Modulation of methane emission by animal-plant-microbe interactions deserves further attention considering the increasing bird populations and changes in wetland vegetation as a consequence of changing land use and climate change.
\end{abstract}

Key words: Graylag Goose (Anser anser); herbivory; methane; methane oxidation; methanogenesis; Phragmites australis; shallow lakes; The Netherlands; waterfowl; wetlands.

\section{INTRODUCTION}

The atmospheric concentration of methane has almost tripled over the last 200 years (Wuebbles and Hayhoe 2002). Methane is 20 times more effective at absorbing infrared radiation than $\mathrm{CO}_{2}$, and contributes $17 \%$ to the total radiative forcing (Solomon et al. 2007). About 30\% of the annual methane emission to the atmosphere originates from natural wetlands (Solomon et al. 2007), whereas wetlands only occupy $3.8 \%$ of the earth's land surface (Aselmann and Crutzen 1989). Next to being a major source, wetlands are among the most prominent sources of unexplained spatial and temporal variability in global methane emission estimates (Bousquet et al. 2006), necessitating the investigation of controlling factors of methane emission from wetlands.

Major methane-emitting sites in wetlands are the littoral zones where helophytes form a conduit for methane produced in the soil or sediment to the

Manuscript received 1 July 2010; revised 29 October 2010; accepted 1 December 2010. Corresponding Editor: J. B. Yavitt.

${ }^{3}$ Present address: Department of Ecology and Biodiversity, Institute of Environmental Biology, Utrecht University, P.O. Box 80084, NL-3508 TB Utrecht, The Netherlands.

${ }^{4}$ Corresponding author. E-mail: p.bodelier@nioo.knaw.nl atmosphere by providing a sediment-root-stem-atmosphere continuum (Bergstrom et al. 2007, Laanbroek 2010). In dense vegetation stands in natural wetlands, transport through intact emergent macrophytes may account for $90 \%$ of the methane emission (Bergstrom et al. 2007). The abundance of submerged and emergent wetland plants may be strongly affected by herbivorous waterbirds and fish (Van Eerden et al. 1997, Marklund et al. 2002, Van den Wyngaert et al. 2003, Gauthier et al. 2005). A meta-analysis by Ostendorp (1989) concludes that various grazers and especially Graylag Geese (Anser anser) seriously harm healthy stands of emergent helophytes at different locations across Europe.

Bodelier et al. (2006) showed that swan-grazing on belowground tubers of a submerged macrophyte strongly reduced methane production activity of methanogenic microorganisms. However, whereas especially emergent helophytes have a disproportionally strong effect on methane emission, the impact of grazing on methane emission from helophytes remains largely unknown.

Intact plants form a conduit for gases to be exchanged between the soil and the atmosphere, which can be by active transport or by diffusion (Armstrong et al. 1996, Brix et al. 1996, Laanbroek 2010). In intact wetland 


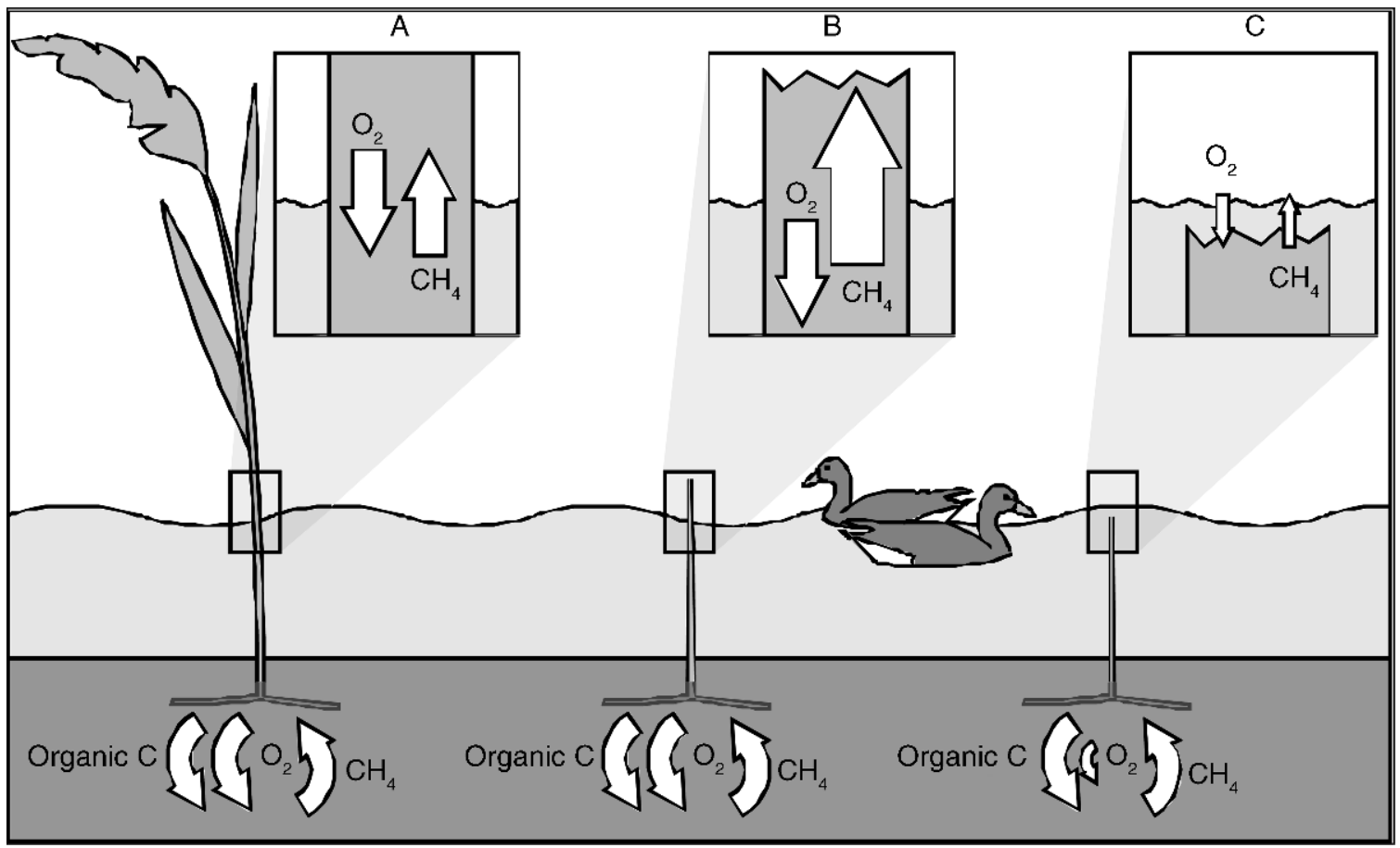

FIG. 1. Schematic figure of the potential immediate and long-term effects of herbivores on emergent macrophytes and subsequent methane release from wetlands in The Netherlands. The size of the arrows indicates the relative amount of methane escaping to the atmosphere. (A) In a non-grazed situation there is an influx of oxygen $\left(\mathrm{O}_{2}\right)$ and an efflux of methane $\left(\mathrm{CH}_{4}\right)$ through the plant. Falling plant litter, decaying roots, and root exudates provide input of organic carbon in the sediment. Under anaerobic conditions, degradation of this organic carbon generates carbon dioxide, hydrogen, and acetate, which can be converted into methane by methanogenic microbes. Grazing of reeds by geese can occur (B) above and (C) below the water surface. When reeds are grazed above the water surface, a higher $\mathrm{CH}_{4}$ efflux may occur because of the open pathway to the atmosphere. When reeds are grazed below the water surface, methane emission may be slowed substantially because it then can escape only by diffusing through the water in the stem or by ebullition. Vice versa, the transport of oxygen into the sediment will be limited as well for the same reasons and by the absence of the photosynthetically active shoots. This may lead to more anaerobic conditions lowering methane consumption and stimulating methane production, thereby leading to a higher production of methane as compared to non-grazed areas.

plants (Fig. 1A) oxygen moves from the atmosphere through the stems into the roots. Methane, produced by methanogenic microbes as the end product of organic carbon degradation under anoxic conditions (Whiting and Chanton 1993, Conrad 2007), enters the roots from the surrounding soil and makes its way to the atmosphere (Fig. 1A). In our system, plants are grazed by geese above or below the water level. In the case of grazing above the water level (Fig. 1B) the standing stem can act as a pathway for exchange of gases between sediment and atmosphere (Brix et al. 1996), which may result in a higher diffusive flux of methane as shown in clipping experiments with wetland plants (Ding et al. 2005, Cheng et al. 2007). When the plants are grazed below the water surface, methane can only escape to the atmosphere via diffusion or ebullition through the water which, in case of diffusion, is orders of magnitude slower than in air (Chanton et al. 1997, Cheng et al. 2007), resulting in lower methane emission as compared to intact plants when diffusive flux is the major pathway of emission (Fig. 1C). Reduction of shoot biomass by grazing will also lower the amount of oxygen and carbon released into the soil, both potentially negatively influencing the production of methane by methanogenic archaea as well as the consumption of methane by methanotrophic bacteria (Segers 1998, Bodelier et al. 2000, Conrad 2007).

Based on current knowledge of methane emission from helophytes, we hypothesized that goose grazing will modulate methane emission from helophytes. In this study we test this hypothesis and measure whether goose grazing affects methane emission from helophytes in a positive or negative way.

\section{Materials And Methods}

\section{Study system}

We conducted our study in an oligotrophic lake (Waterleidingplas, $52^{\circ} 12^{\prime} \mathrm{N}, 5^{\circ} 02^{\prime} \mathrm{E}$ ) in the center of The Netherlands. The lake has a shallow littoral zone ( $<2 \mathrm{~m}$ depth), contains abundant macrophyte vegeta- 
tion, and is bordered by narrow reed (Phragmites australis) beds. The lake is 130 ha in area, the bottom consists of a sandy sediment, and the water is dephosphatized, resulting in total phosphorus of 0.015 $\pm 0.007 \mathrm{mg} / \mathrm{L}$ (mean $\pm \mathrm{SE}$ ) with total nitrogen of 1.12 $\pm 0.17 \mathrm{mg} / \mathrm{L}$, and clear water most of the year. The lake has a stable water level throughout the year. The lake is closed to the public, which allows for undisturbed foraging by waterfowl. The only birds that graze on reeds were Graylag Geese (Anser anser), which were most abundant during the molting period in May and June and can reach densities of up to 800 birds visiting the lake (E. S. Bakker, unpublished data).

\section{Experimental design}

In March 2006 we established six exclosures with adjacent controls protruding from the edge of the reed bed into the open water, starting at $\sim 2 \mathrm{~m}$ from shore. The water was $\sim 25 \mathrm{~cm}$ deep on the shore side of the plots and became gradually deeper up to $140 \mathrm{~cm}$ on the open water side of the plots. The exclosures consisted of $2 \times 6 \times 2 \mathrm{~m}$ (length $\times$ width $\times$ height) nets with a mesh size of $2.5 \mathrm{~cm}$ attached to wooden poles (see also Appendix: Fig. A2). The nets extended above the water surface and were covered with wires at the deepest side to prevent geese from entering the exclosure. We never observed traces of Graylag Geese foraging activity in the exclosures during the experiment. We conducted our measurements in 2008, the third year after establishment of the exclosures.

The stems of the reed plants inside and outside the exclosures were counted every 5-6 weeks from May to September within one week before or after the methane flux was measured. The number of intact stems and grazed stems above the water surface were counted in plots $(0.5 \times 0.75 \mathrm{~m})$, located $50 \mathrm{~cm}$ from the shore side of the exclosures ( $\sim 2 \mathrm{~m}$ from the shore). One plot was counted per replicate exclosure and adjacent grazed plot; the average water depth in the plots was $45 \mathrm{~cm}$.

Diffusive methane flux measurements for plots with multiple full-grown plants were conducted using a closed chamber technique (Van der Nat et al. 1998) with transparent acrylic tubes (90\% PAR transmission). For details see the Appendix. We measured the diffusive methane flux in five replicate exclosures and adjacent grazed and non-vegetated plots on 14 July, 5 August, and 2 September. To calculate the diffusive methane flux of individual stems we counted the measured stems in the flux chambers.

Additionally, we measured the diffusive methane flux from individual plants, using small chambers. The chambers were placed over small intact plants and grazed stems in three replicate exclosure-control pairs on 17 June, 4 July, 26 August, and 24 September. The transparent cylindrical chambers with a diameter of 5 $\mathrm{cm}$ and a height of $25 \mathrm{~cm}$ were made of acrylic plastic and closed with a black rubber stopper containing a sampling port (Appendix: Fig. A1). The chambers were strapped to a bamboo stake and lowered over a plant without the rubber stopper to prevent accumulation of methane caused by disturbance. After $5 \mathrm{~min}$ the tube was closed with the rubber stopper, and after another 10 min the first sample was taken. Measurements for the large as well as the small chamber were executed in 50 min. The gas sampling methods were the same as those of the large flux chambers.

Headspace methane, transferred into Venoject tubes, was injected $(200 \mu \mathrm{L})$ into a HP5340 gas chromatograph equipped with a flame ionization detector. Helium $(\mathrm{He})$ was used as a carrier gas with hydrogen $\left(\mathrm{H}_{2}\right)$ and synthetic air as burning gases. The oven temperature was $100^{\circ} \mathrm{C}$. Calibration was performed using certified calibration gas (1021 ppm by volume $\mathrm{CH}_{4}$ ).

After methane flux measurements with the large chambers, three soil cores (4 $\mathrm{cm}$ diameter, $2 \mathrm{~cm}$ depth) were taken from each measured plot (July, $n=4$ plots; August and September, $n=5$ ) in and outside the exclosure, for analysis of potential methane oxidation (PMO), potential methane production (PMP), soil moisture, soil density, and organic matter content. Soil moisture was determined as mass loss after drying (48 h, $70^{\circ} \mathrm{C}$ ). The organic matter content of the soil was determined by measuring the mass loss after ignition of the dry soil at $550^{\circ} \mathrm{C}$ for $4 \mathrm{~h}$. The soil density was measured by determining the amount of water added to a volume of soil $(\sim 5 \mathrm{~g})$ to reach a total volume of $25 \mathrm{~mL}$.

Potential methane production activity (PMP) was determined as described by Bodelier et al. (2006), while potential methane oxidation activity (PMO) was described by Bodelier and Frenzel (1999). For more details see the Appendix.

Cores (4 cm diameter, $18 \mathrm{~cm}$ depth) were taken outside the exclosures to measure pore water methane. These were divided into slices of $2 \mathrm{~cm}$ depth in the field. To determine the amount of methane in the pore water of the slices, we transferred a slice to a 150 -mL flask with $30 \mathrm{~mL}$ demineralized water, sealed the flask with a rubber stopper, and shook the flask to extract the methane out of the pore water. Less than one hour later we analyzed the methane content in the laboratory with the gas chromatograph and expressed it in $\mu$ moles $\mathrm{CH}_{4}$ per liter pore water.

\section{Statistical analysis}

All data were tested for normal distribution by a Kolmogorov-Smirnov test and, if necessary, log-transformed to normal distribution. All data measured for several months were analyzed by a repeated-measures ANOVA with grazing treatment as fixed factor and time of measurement as the repeated factor. All statistical analyses were done with Statistica 7 (StatSoft, Tulsa, Oklahoma, USA). 


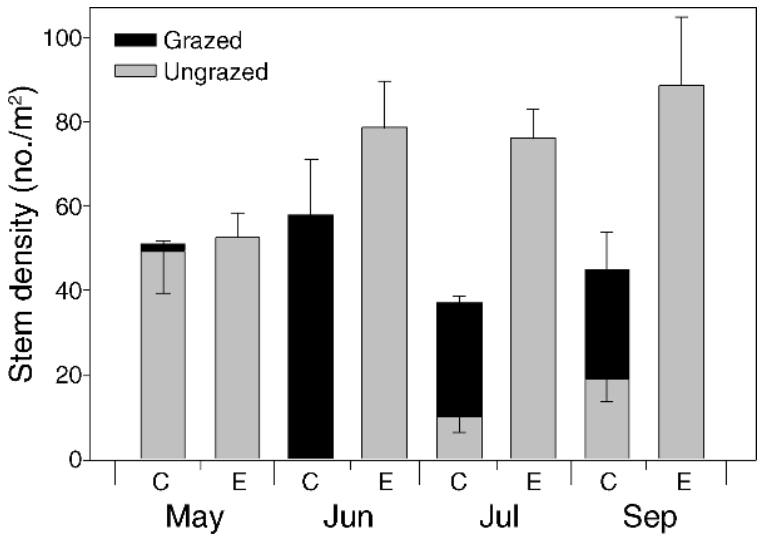

FIG. 2. Stem density (mean $\pm \mathrm{SE}, n=6$ ) of reeds (Phragmites australis) from May to September 2008 in control plots (C) and exclosures (E) in an oligotrophic lake (Waterleidingplas, The Netherlands). Stems grazed or ungrazed by geese are indicated separately.

\section{RESUlTS}

Graylag Geese had a strong effect on the reed vegetation (Fig. 2; Appendix: Fig. A2). In May, only a few stems were grazed, but in June every stem in the unprotected plots, with an average of $58 \mathrm{stems} / \mathrm{m}^{2}$, was grazed. Only broken culms were left emerging $\sim 20 \mathrm{~cm}$ above the water surface. From July to September new reed plants appeared or grazed plants sprouted again, but the stem density was about one-half that inside the exclosure, because plants simply disappeared below the water surface after being grazed upon. From May through September grazing significantly reduced reed stem density in the control plots $\left(F_{3,30}=3.36, P=0.031\right)$.

Diffusive methane flux was higher from grazed individual stems compared to ungrazed stems in June, July, and August, but not in September (Fig. 3A, measurements from the small flux chambers). Measurements in late September with the small flux chambers showed a drop in diffusive methane flux of the grazed plots because of the degradation of the grazed stems (Fig. 3A). The old grazed stems were penetrated by water reducing the flow of air through the stems. As a result the main effect of grazing treatment was not significant, but there was a significant interaction between grazing treatment and time (Table 1). When omitting the September data from the ANOVA analyses, the grazing effect on diffusive methane flux from single stems is significant, supporting the observation that the emission from grazed stems was higher from June through August (Table 1, Fig. 3A). The average diffusive methane flux from grazed culms was more than double the average from intact plants in the exclosure from July to September (Fig. 3B; measured with the large chambers and calculated per stem). This effect was marginally significant (Table 1). From July to Septem- ber we found a significant grazing treatment effect on diffusive methane flux on a plot basis (Table 1, Fig. 3C). The diffusive methane flux in grazed plots was 4.8 times higher per square meter than in exclosed plots in the measured months. The mean diffusive methane flux of the plots without emerging plants was not significantly different compared to grazed or ungrazed plots.
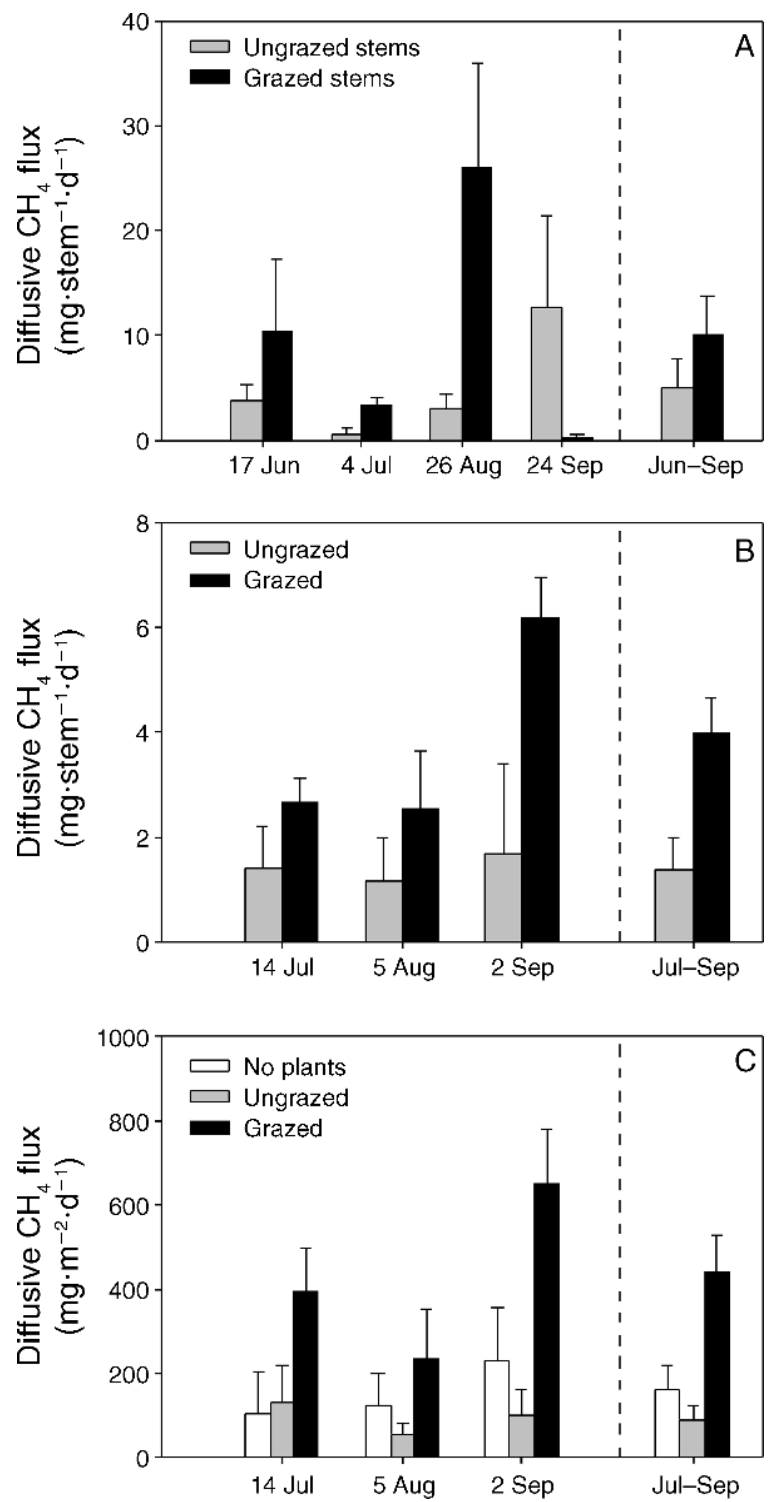

FIG. 3. (A) Methane flux per stem (mean + SE) measured in grazed and ungrazed individual stems outside exclosures with the small flux chambers. (B) The integrated methane flux of the surface area covered by the large flux chambers divided by the numbers of stems in the chamber. (C) Methane flux per surface area was measured each month, with the large flux chambers inside the exclosures and in the adjacent grazed and nonvegetated (no plants) plots. In panel (A), $n=5$ plots, whereas in panels (B) and (C), $n=4$ in July and $n=5$ in August and September. 
TABLE 1. Results of a repeated-measures ANOVA for methane emissions from reeds (Phragmites australis) measured in exclosure and control treatments with small and large chambers in an oligotrophic lake in The Netherlands.

\begin{tabular}{lccc}
\hline \hline Factor, by measurement type & df & $F$ & $P$ \\
\hline Per stem (small chambers) & & & \\
$\quad$ Treatment & 1,4 & 2.49 & 0.190 \\
$\quad$ Time & 3,12 & 4.14 & 0.031 \\
$\quad$ Time $\times$ treatment & 3,12 & 4.62 & 0.023 \\
Per stem (small chambers, Sep excluded) & & \\
$\quad$ Treatment & 1,4 & 19.97 & 0.011 \\
Time & 2,12 & 7.39 & 0.015 \\
Time $\times$ treatment & 2,12 & 1.10 & 0.378 \\
Per stem (large chambers) & & & \\
Treatment & 1,6 & 5.47 & 0.058 \\
Time & 2,12 & 1.02 & 0.389 \\
Time $\times$ treatment & 2,12 & 0.03 & 0.973 \\
Per m ${ }^{2}$ (large chambers) & & & \\
Treatment & 1,6 & 10.60 & 0.017 \\
Time & 2,12 & 0.18 & 0.834 \\
Time $\times$ treatment & 2,12 & 0.39 & 0.685 \\
\hline
\end{tabular}

Notes: Testing of methane emission per stem measured with the small chambers revealed a significant interaction between grazing treatment and time, which was due to the measurement in September (Fig. 3A); therefore, data were subsequently tested excluding the month of September.

Grazing had no effect on the potential methane oxidation (PMO) or production (PMP) in the sediment (Appendix: Table A1). PMO and PMP did change over time; PMO is significantly higher in August compared to July and September and the PMP increased significantly from July to September. The moisture content, organic matter content, and density of the soil did not differ between treatments or in time (Appendix: Table A1). The methane content of the pore water increased significantly with increasing sediment depth $\left(F_{3,32}=\right.$ 17.14, $P<0.001)$ from $48 \mu \mathrm{mol} / \mathrm{L}$ at the soil surface to $>660 \mu \mathrm{mol} / \mathrm{L}$ in the layers deeper than $12 \mathrm{~cm}$.

\section{Discussion}

Wetlands are not only the most important source of atmospheric methane (Solomon et al. 2007), but also are among the most prominent sources of unexplained spatial and temporal variability in global methane emission estimates (Bousquet et al. 2006). The presence of wetland plants, providing methanogenic archaea with the necessary carbon (Conrad 2007) and forming a conduit for the escape of methane to the atmosphere, is the most important feature responsible for this important role of wetlands in global methane cycling (Laanbroek 2010). The reduction of the unexplained variance and variability in global methane emissions models requires mechanistic knowledge of the factors that affect and regulate the formation, degradation, and emission of methane in wetland systems. The results presented in this paper reveal an as yet completely ignored factor, regulating methane emission from wetlands. Grazing by herbivorous waterfowl is put forward as a factor to be further explored in methane emission from wetland ecosystems.

Clipping of shoots of emergent macrophytes has generally been used to demonstrate the transport of oxygen into the rhizosphere on one hand and the facilitation of methane escape from the soil on the other (Ding et al. 2005, Laanbroek 2010). Surprisingly, a natural biological factor resembling clipping, i.e., grazing by waterfowl, has never been investigated, despite the large numbers of herbivorous water birds present in wetlands globally. In our study, the diffusive methane flux per area from grazed plots was almost five times higher than from exclosed plots, harboring intact vegetation. Considering the fact that the observed range of emission (100-700 $\left.\mathrm{mg} \mathrm{CH} \mathrm{CH}_{4} \cdot \mathrm{m}^{-2} \cdot \mathrm{d}^{-1}\right)$ observed in Lake Waterleidingplas is in the same range as from natural wetlands (Bridgham et al. 2006, Ding and Cai 2007, Saarnio et al. 2009) as well as rice paddies (Xie et al. 2010) and higher than commonly found in Phragmites stands (Duan et al. 2009), the grazing effect may be a significant regulator of global methane emission from wetlands. The area of grazed reed in Lake Waterleidingplas is $\sim 12.5$ ha. This would mean that when geese are banned from the lake, the daily emission of methane from the grazed area could decrease from 5.55 to $1.15 \mathrm{~kg}$. However, we have to keep in mind that we have no idea how grazing possibly affects methane ebullition, which we did not assess in this study but, which over long periods of time, may significantly contribute to the amount of methane emitted from the lake. Next to this, these numbers do not take into account that there is a daily methane emission pattern for Phragmites (Van der Nat et al. 1998) connected to temperature, moisture, and photosynthetic activity. Another factor that has to be considered in these estimates is that when stems are grazed down to below the waterline, diffusive methane flux is slower as compared to an open stem as has been demonstrated in clipping experiments (Kelker and Chanton 1997). Additionally, when grazed stems age, they may fill up with water resulting in the same reduced methane transport, as observed in the September measurements on single stems that were taken on 24 September. Measurements taken on multiple stems with the large chambers still showed a much higher diffusive methane flux from the grazed stems in September, compared to ungrazed stems (Fig. 3B). These measurements were taken on 2 September, when grazed stems were still intact (B. J. J. Dingemans, personal observation). This increased diffusive flux from grazed stems in early September measured with the large chambers is in the same order of magnitude as the measurement on 26 August on individual stems taken with the small tubes (Fig. 3A), illustrating the strong impact of stem degradation that rapidly occurs in September. Hence, 
it is obvious that upscaling of the observed effects on an annual scale requires information with a higher temporal resolution on underlying mechanisms and dynamics.

Nevertheless, the grazing effect is also obvious and persistent over longer time periods, suggesting an effect of the removal of the shoots on belowground physical and biological processes. Basically, reduction of the diffusion resistance by removing the shoot is the most likely explanation of the observed effects in the short term, leading to preferred release of methane through the top of the grazed stem instead of the base of the stem, which occurs normally in intact plants (Whiting and Chanton 1996, Van der Nat et al. 1998). The faster escape of methane from the grazed stems may lead to a proportional change of diffusive flux vs. ebullition, explaining the long-term effects. Methane concentration in the pore water around the roots of grazed stems will decrease faster, resulting in less bubble formation due to saturation of the pore water. Hence, more methane would stay dissolved in pore water around the roots of grazed stems.

A lowering of the proportion of the produced methane that is oxidized could also explain the grazing effect on a longer time scale. Removal of the shoot will cut off the transport of oxygen down to roots and rhizomes, which may lead to stimulation of anaerobic methane formation and a lowering of the aerobic methane oxidation, resulting in higher methane release through the stubbles (see Fig. 1). However, the soil methane production and methane oxidation activities we measured did not differ between grazed and control plots. We have to keep in mind though that these potential methane production and oxidation analyses were in vitro assays under optimal conditions yielding potential activities with soil derived near the roots and rhizomes, but not actually on the roots, thereby not necessarily reflecting the in situ activity. Nevertheless, the observed in vitro rates were in the same range as observed for rice fields (Bodelier et al. 2000, Kruger and Frenzel 2003), lake sediments (Bodelier et al. 2006), and river floodplains (Kemnitz et al. 2004, Steenbergh et al. 2010) and hence, representative for wetland habitats. Also, the measured pore water methane concentrations were in the same range as observed in rice field soil (Bodelier et al. 2000) and also displayed a characteristic depth distribution. Hence, taking all measured parameters into account, our site can be regarded as a representative wetland in terms of methane cycling.

Having observed the enhanced methane release caused by herbivorous birds, the question arises as to what the significance is of this observation for methane emission from worldwide wetlands. Considering the well-documented presence and effects of herbivorous waterfowl on aquatic macrophytes (e.g., Van Eerden et al. 1997, Van den Wyngaert et al. 2003, Gauthier et al. 2005, Hidding et al. 2009) in wetlands systems globally, it is highly unlikely that our observations are of incidental nature. Nevertheless, methane emission has to our knowledge never been assessed in any plantherbivore interaction study. Waterfowl can reduce stands of wetland plants by grubbing for tubers and rhizomes (Hidding et al. 2009), which may result in an altered $\mathrm{C}$ balance of ecosystems (van der Wal et al. 2007). Grubbing activities of waterfowl feeding on belowground plant organs have been shown to affect the underlying microbial processes of methane emission, methane production, and oxidation (Bodelier et al. 2006). However, with respect to effects on methane cycling when aboveground parts of wetland plants are removed by herbivores, nothing is known. It is evident, however, for our reed case that in grazed stands methane will escape to the atmosphere at a faster rate of diffusion, leading to dynamics and variability in methane emission that may not be accounted for mechanistically in methane emission models. Additionally, common reed, which seems to be rather palatable to grazing geese, is expanding as an invasive species in many important wetland areas globally (Chambers et al. 2008, Ji et al. 2009). Combined with the effects of human land use and climate change on distribution and numbers of waterfowl visiting wetlands globally (Petrie and Francis 2003, Bairlein and Huppop 2004, BohningGaese and Lemoine 2004, Gauthier et al. 2005, Van Eerden et al. 2005, van der Wal et al. 2007), it is evident that more research is necessary to obtain an understanding regarding the impact of waterfowl on dynamics of methane emission from wetland areas.

Because our study focused on only one plant and bird species, the first research priority is to assess grazing effects on other plant species and by other herbivore species. This is especially important because various plant species differ in important features that influence gas transport from wetlands (see Laanbroek 2010). Additionally, plant species affect the underlying microbial processes in different ways, which very much depends on their oxygen and carbon release into the soil (see Laanbroek 2010). Once it is established that the grazing effect on methane emission is a general phenomenon in wetlands, experimental manipulative experiments have to be executed that test the influence of important physical parameters, especially the ones regulating herbivore-plant interactions. The hydrology (i.e., water level) is a major regulator in this relationship because it determines whether the waterfowl have access to the vegetation (Bart and Earnst 1991) and to whether the stems will be grazed down to above or below the water level. The latter can have a major influence on stem methane release as was shown by clipping experiments (Ding et al. 2005). Factors that determine site selection by birds (for example, predation risk or disturbance) may indirectly affect their effect on methane emission as spatial patterns of habitat use 
determine the grazing impact of waterfowl on emergent macrophytes (Salski and Holsten 2009).Temporal aspects will also be one of the central points to address. The grazing effect may be temporary because regrowth of shoots can occur when grazing ceases, as is the case with Graylag Geese that specifically graze on reeds during their molt (Van Eerden et al. 1997). Long-term grazing of areas may change vegetation composition and thereby methane cycling microbial processes. Different species of aquatic herbivores have been documented to consume emergent macrophytes, including waterfowl (feral geese, Mute Swan, and Common Coot), mammals (muskrat, coypu), and fish (grass carp) (Boorman and Fuller 1981, Ostendorp 1989, Lodge 1991, Connors et al. 2000). The quantitative effects of these herbivores on methane emission depend strongly on whether grazing occurs below or above the water surface, as discussed earlier for reeds. Generally, little is known about the impact of different species of aquatic herbivores on emergent macrophytes, let alone of their potential effects on methane emission. However, in all possible directions of research previously mentioned, it will be necessary to also assess the contribution of ebullition to total methane emission and the effects of grazing on this aspect of methane emission to fully evaluate the impact of plant-herbivore interactions on methane emission from wetlands.

\section{CONCLuSION}

Grazing of Graylag Geese on shoots of the emergent wetland plant Phragmites australis can lead to temporarily enhanced methane emission from wetland habitats. Removal of shoots facilitates the escape of methane from the sediment by diffusion. The impact and value of these observations for understanding variability in methane emission patterns from wetland habitats will require research to assess whether our observations are a generally occurring phenomenon in wetlands worldwide with different herbivore and plant species. Understanding the mechanistic basis and controls of the effects of plant-animal interactions on methane emissions will require substantial experimentation with a focus on biological factors as well as on the influence of physical factors.

\section{ACKNOWLEDGMENTS}

The authors thank Gerard ter Heerdt and Waternet for granting access to Lake Waterleidingplas and supplying exclosure materials, and Koos Swart, Thijs de Boer, and Peter de Vries for assistance in building the waterfowl exclosures. We thank Naomi Huig for her help in measuring reed stems and Marion Meima-Franke for assisting the methane flux measurements. This paper is publication number 4916 of the Netherlands Institute of Ecology (NIOO-KNAW).

\section{Literature Cited}

Armstrong, J., W. Armstrong, P. M. Beckett, J. E. Halder, S Lythe, R. Holt, and A. Sinclair. 1996. Pathways of aeration and the mechanisms and beneficial effects of humidity- and
Venturi-induced convections in Phragmites australis (Cav) Trin ex Steud. Aquatic Botany 54:177-197.

Aselmann, I., and P. J. Crutzen. 1989. Global distribution of natural fresh-water wetlands and rice paddies, their net primary productivity, seasonality and possible methane emissions. Journal of Atmospheric Chemistry 8:307-358.

Bairlein, F., and O. Huppop. 2004. Migratory fuelling and global climate change. Pages $33-47$ in A. P. Moller, W. Fielder, and P. Berthold, editors. Birds and climate change. Advances in Ecological Research 35.

Bart, J., and S. Earnst. 1991. Use of wetlands by grazing waterfowl in northern Alaska during late summer. Journal of Wildlife Management 55:564-568.

Bergstrom, I., S. Makela, P. Kankaala, and P. Kortelainen. 2007. Methane efflux from littoral vegetation stands of southern boreal lakes: an upscaled regional estimate. Atmospheric Environment 41:339-351.

Bodelier, P. L. E., and P. Frenzel. 1999. Contribution of methanotrophic and nitrifying bacteria to $\mathrm{CH}_{4}$ and $\mathrm{NH}_{4}^{+}$ oxidation in the rhizosphere of rice plants as determined by new methods of discrimination. Applied and Environmental Microbiology 65:1826-1833.

Bodelier, P. L. E., A. P. Hahn, I. R. Arth, and P. Frenzel. 2000. Effects of ammonium-based fertilisation on microbial processes involved in methane emission from soils planted with rice. Biogeochemistry 51:225-257.

Bodelier, P. L. E., M. Stomp, L. Santamaria, M. Klaassen, and H. J. Laanbroek. 2006. Animal-plant-microbe interactions: direct and indirect effects of swan foraging behaviour modulate methane cycling in temperate shallow wetlands. Oecologia 149:233-244.

Bohning-Gaese, K., and N. Lemoine. 2004. Importance of climate change for the ranges, communities and conservation of birds. Pages 211-236 in A. P. Moller, W. Fielder, and P. Berthold, editors. Birds and climate change. Advances in Ecological Research 35.

Boorman, L. A., and R. M. Fuller. 1981. The changing status of reedswamp in the Norfolk broads. Journal of Applied Ecology 18:241-269.

Bousquet, P., et al. 2006. Contribution of anthropogenic and natural sources to atmospheric methane variability. Nature 443:439-443.

Bridgham, S. D., J. P. Megonigal, J. K. Keller, N. B. Bliss, and C. Trettin. 2006. The carbon balance of North American wetlands. Wetlands 26:889-916.

Brix, H., B. K. Sorrell, and H. H. Schierup. 1996. Gas fluxes achieved by in situ convective flow in Phragmites australis. Aquatic Botany 54:151-163.

Chambers, R. M., K. J. Havens, S. Killeen, and M. Berman. 2008. Common reed Phragmites australis occurrence and adjacent land use along estuarine shoreline in Chesapeake Bay. Wetlands 28:1097-1103.

Chanton, J. P., G. J. Whiting, N. E. Blair, C. W. Lindau, and P. K. Bollich. 1997. Methane emission from rice: stable isotopes, diurnal variations, and $\mathrm{CO}_{2}$ exchange. Global Biogeochemical Cycles 11:15-27.

Cheng, X. L., R. H. Peng, J. Q. Chen, Y. Q. Luo, Q. F. Zhang, S. Q. An, J. K. Chen, and B. Li. 2007. $\mathrm{CH}_{4}$ and $\mathrm{N}_{2} \mathrm{O}$ emissions from Spartina alterniflora and Phragmites australis in experimental mesocosms. Chemosphere 68:420-427.

Connors, L. M., E. Kiviat, P. M. Groffman, and R. S. Ostfeld. 2000. Muskrat (Ondatra zibethicus) disturbance to vegetation and potential net nitrogen mineralization and nitrification rates in a freshwater tidal marsh. American Midland Naturalist 143:53-63.

Conrad, R. 2007. Microbial ecology of methanogens and methanotrophs. Advances in Agronomy 96:1-63. 
Ding, W. X., and Z. C. Cai. 2007. Methane emission from natural wetlands in China: summary of years 1995-2004 studies. Pedosphere 17:475-486.

Ding, W. X., Z. C. Cai, and H. Tsuruta. 2005. Plant species effects on methane emissions from freshwater marshes. Atmospheric Environment 39:3199-3207.

Duan, X. N., X. K. Wang, and Z. Y. Ouyang. 2009. Influence of common reed (Phragmites australis) on $\mathrm{CH}_{4}$ production and transport in wetlands: results from single-plant laboratory experiments. Water, Air, and Soil Pollution 197:185191.

Gauthier, G., J. F. Giroux, A. Reed, A. Bechet, and L. Belanger. 2005. Interactions between land use, habitat use, and population increase in greater snow geese: what are the consequences for natural wetlands? Global Change Biology $11: 856-868$.

Hidding, B., B. A. Nolet, T. de Boer, P. P. de Vries, and M. Klaassen. 2009. Compensatory growth in an aquatic plant mediates exploitative competition between seasonally tied herbivores. Ecology 90:1891-1899.

Ji, Y. H., G. S. Zhou, G. H. Lv, X. L. Zhao, and Q. Y. Jia. 2009. Expansion of Phragmites australis in the Liaohe Delta, north-east China. Weed Research 49:613-620.

Kelker, D., and J. Chanton. 1997. The effect of clipping on methane emissions from Carex. Biogeochemistry 39:37-44.

Kemnitz, D., K. J. Chin, P. Bodelier, and R. Conrad. 2004. Community analysis of methanogenic archaea within a riparian flooding gradient. Environmental Microbiology 6:449-461.

Kruger, M., and P. Frenzel. 2003. Effects of N-fertilisation on $\mathrm{CH}_{4}$ oxidation and production, and consequences for $\mathrm{CH}_{4}$ emissions from microcosms and rice fields. Global Change Biology 9:773-784.

Laanbroek, H. J. 2010. Methane emission from natural wetlands: interplay between emergent macrophytes and soil microbial processes. A mini-review. Annals of Botany 105:141-153.

Lodge, D. M. 1991. Herbivory on freshwater macrophytes. Aquatic Botany 41:195-224.

Marklund, O., H. Sandsten, L. A. Hansson, and I. Blindow. 2002. Effects of waterfowl and fish on submerged vegetation and macroinvertebrates. Freshwater Biology 47:2049-2059.

Ostendorp, W. 1989. 'Die-back' of reeds in Europe - a critical review of literature. Aquatic Botany 35:5-26.

Petrie, S. A., and C. M. Francis. 2003. Rapid increase in the lower Great Lakes population of feral mute swans: a review and a recommendation. Wildlife Society Bulletin 31:407-416.

Saarnio, S., W. Winiwarter, and J. Leitao. 2009. Methane release from wetlands and watercourses in Europe. Atmospheric Environment 43:1421-1429.

Salski, A., and B. Holsten. 2009. Fuzzy knowledge- and databased models of damage to reeds by grazing of Greylag Geese. Ecological Informatics 4:156-162.
Segers, R. 1998. Methane production and methane consumption: a review of processes underlying wetland methane fluxes. Biogeochemistry 41:23-51.

Solomon, S., D. Qin, M. Manning, Z. Chen, M. Marquis, K. B. Averyt, M. Tignor, and H. L. Miller. 2007. Contribution of Working Group I to the Fourth Assessment Report of the Intergovernmental Panel on Climate Change. Cambridge University Press, Cambridge, United Kingdom.

Steenbergh, A. K., M. M. Meima, M. Kamst, and P. L. E. Bodelier. 2010. Biphasic kinetics of a methanotrophic community is a combination of growth and increased activity per cell. FEMS Microbiology Ecology 71:12-22.

Van den Wyngaert, I. J. J., L. D. Wienk, S. Sollie, R. Bobbink, and J. T. A. Verhoeven. 2003. Long-term effects of yearly grazing by moulting Greylag geese (Anser anser) on reed (Phragmites australis) growth and nutrient dynamics. Aquatic Botany 75:229-248.

Van der Nat, F., J. J. Middelburg, D. Van Meteren, and A. Wielemakers. 1998. Diel methane emission patterns from Scirpus lacustris and Phragmites australis. Biogeochemistry 41:1-22.

van der Wal, R., S. Sjogersten, S. J. Woodin, E. J. Cooper, I. S. Jonsdottir, D. Kuijper, T. A. D. Fox, and A. D. Huiskes. 2007. Spring feeding by pink-footed geese reduces carbon stocks and sink strength in tundra ecosystems. Global Change Biology 13:539-545.

Van Eerden, M. R., R. H. Drent, J. Stahl, and J. P. Bakker. 2005. Connecting seas: western Palaearctic continental flyway for water birds in the perspective of changing land use and climate. Global Change Biology 11:894-908.

Van Eerden, M. R., M. J. J. E. Loonen, and M. Zijlstra. 1997. Moulting Greylag geese Anser anser defoliating a reed marsh Phragmites australis: seasonal constraints versus long-term commensalism between plants and herbivores. Pages 239-264 in M. R. Van Eerden, editor. Patchwork: patch use, habitat exploitation and carrying capacity for water birds in Dutch freshwater wetlands. Ministerie van Verkeer en Waterstaat, Directoraat-Generaal Rijkswaterstaat, Directie IJsselmeergebied, Lelystad, The Netherlands.

Whiting, G. J., and J. P. Chanton. 1993. Primary production control of methane emission from wetlands. Nature 364:794795 .

Whiting, G. J., and J. P. Chanton. 1996. Control of the diurnal pattern of methane emission from emergent aquatic macrophytes by gas transport mechanisms. Aquatic Botany 54:237253.

Wuebbles, D. J., and K. Hayhoe. 2002. Atmospheric methane and global change. Earth-Science Reviews 57:177-210.

Xie, B. H., X. H. Zheng, Z. X. Zhou, J. X. Gu, B. Zhu, X. Chen, Y. Shi, Y. Y. Wang, Z. C. Zhao, C. Y. Liu, Z. S. Yao, and J. G. Zhu. 2010. Effects of nitrogen fertilizer on $\mathrm{CH}_{4}$ emission from rice fields: multi-site field observations. Plant and Soil 326:393-401.

\section{APPENDIX}

Additional materials and methods, including a diagram showing the chambers used in the methane flux measurements, photographs of the waterfowl exclosures, and a table showing potential methane oxidation and production, soil moisture content, soil organic matter content, soil density per month in the exclosed and control plots, and the results of a repeated-measures ANOVA for these soil characteristics (Ecological Archives E092-095-A1). 